\title{
APLIKASI REPOSITORY RESEP MAKANAN PENDAMPING AIR SUSU IBU (MP-ASI) DENGAN MODEL USER GENERATED CONTENT
}

\author{
Marwa Sulehu ${ }^{1}$, Tamra ${ }^{2}$ \\ Sistem Informasi STMIK AKBA ${ }^{1}$, Sistem Informasi STMIK AKBA ${ }^{2}$ \\ Email: marwa.sulehu@akba.ac.id ${ }^{1}$, tamra@akba.ac.id ${ }^{2}$
}

\begin{abstract}
ABSTRAK
Resep menu mp-asi yang akan di data dalam aplikasi repository ini telah dikelompokan berdasarkan umur, bahan utama pembuatnya, jenis dan kandungannya menggunakan konsep User Generated Content (UGC). Konsep UGC ini memanfaatkan member yang ada di dalam aplikasi social media ini untuk berbagai resep dengan memposting ke dalam account mereka tanpa bayar (gratis). Penelitian aplikasi sosial media berbasis UGC ini memanfaatkan teknologi web dengan menerapakan eXtreme Programming (XP) sebagai framework pengembangan sistemnya serta Uniform Modeling Language (UML) dalam merancang sistemnya. Dengan adanya aplikasi sosial media ini netter memiliki wadah dan semakin memudahkan para penggunanya untuk mempublikasikan menu resep mereka yang secara tidak langsung memberi inspirasi kepada pengguna sosial media ini akan pentingnya pemenuhan gizi untuk perkembangan anak dengan berbahan lokal yang ada disekitar kita.
\end{abstract}

Kata Kunci: MP-ASI, eXtreme Programming, User Generated Content

\section{ABSTRACT}

The breastfeeding sides dish recipes that will put into the repository application have been classified by age, the main ingredient the type and content using the concept of User Generated Content (UGC). This UGC concept utilizes members that are in this social media application for various recipes by posting to their account without payment (free). This UGCbased social media application research utilizes web technology by applying eXtreme Programming (XP) as a system development framework and Uniform Modeling Language $(U M L)$ in designing the system. With this social media application, the netter has a place and makes it easier for users to publish their recipe menu which indirectly inspires these social media users on the importance of fulfilling local nutrition for child development around us.

Keywords: MP-ASI, eXtreme Programming, User Generated Content

\section{Pendahuluan}

Kesehatan bayi dan balita terkait dengan pemenuhan gizi yang tepat masih menjadi penyebab kesakitan dan kematian dengan angka yang cukup tinggi di Indonesia. Permasalahan-pemasalahan yang ada ini disebabkan masih kurangnya pengetahuan dan informasi cara penyajian makanan khususnya makanan pendamping air susu ibu (mp-asi). Terkait masalah ini, memunculkan satu solusi dengan membuat teknologi yang bisa mewadahi para netter untuk bisa berbagi pengetahuan seputar resep menu mp-asi. Solusi yang dipilih dengan menggunakan konsep sosial media berbasis User Generated Content (UGC). Konsep UGC ini memanfaatkan member yang ada di dalam aplikasi social media ini 
untuk berbagai resep dengan memposting ke dalam account mereka tanpa bayar (gratis). Resep menu akan di bentuk berupa repository yang akan dikelompokan berdasarkan umur, bahan utama pembuatnya, jenis dan kandungannya..

\section{Tinjauan Pustaka}

\subsection{MP-ASI}

Menurut WHO tahun 2003 dalam [1] dan [2], Makanan Pendamping ASI (MP-ASI) adalah makanan atau minuman selain ASI yang mengandung nutrisi, yang diberikan kepada bayi selama periode pemberian makanan peralihan (complementary feeding) yaitu pada saat makanan atau minuman lain diberikan bersama pemberian ASI.

Berdasarkan [1] dan [2] Bayi usia 6 bulan, sejalan dengan bertambahanya usia bayi, kebutuhan nutrisi baik makronutrien maupun mikronutrien tidakdapat lagi terpenuhi hanya dengan ASI. Selain itu, keterampilan makan terus berkembang dan bayi mulai memperlihatkan minat akan makanan lain selain yang berbentuk susu (ASI).

\subsection{Repository}

Produksi dapat didefinisikan sebagai suatu proses yang menciptakan atau menambah nilai/guna atau manfaat baru. Guna atau manfaat mengandung pengertian kemampuan barang atau jasa untuk memenuhi kebutuhan manusia. Jadi produksi meliputi semua aktivitas menciptakan barang dan jasa [3]

\subsection{User Generated Content}

User Generated Content (UGC) adalah segala isi yang dibuat dan/atau dipublikasikan oleh pengguna media siber, antara lain artikel, gambar, komentar, suara, video, dan berbagai bentuk unggahan yang melekat pada media siber seperti blog, forum, komentar pembaca atau pemirsa, dan bentuk lain [4]

\section{Metode Perancangan \\ 3.1 Use Case Diagram}

Use case diagram pada gambar 1 dapat dijelaskan bahwa terdapat 3 aktor yang terlibat dan menggunakan aplikasi repository ini terdiri dari aktor admin sebagai pengelola sistem, aktor member yang memiliki hak untuk mengupload resep ke dalam aplikasi termasuk memberikan komentar pada resep yang diupload oleh member lainnya dan aktor non member. Aktor non member ini hanya dimungkinkan untuk melihat resep-resep dan memfilter berdasarkan kriteria-kriteria yang sudah disiapkan dalam sistem tanpa melalui proses login terlebih dahulu.

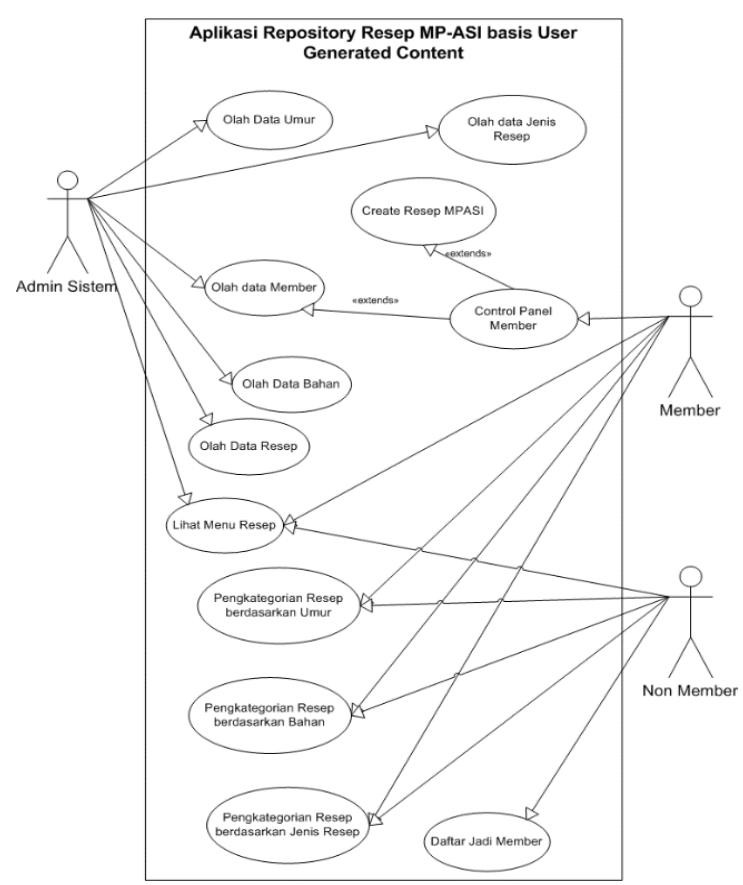

Gambar 1 Use case diagram Admin

Relasi tabel merupakan kumpulan dari beberapa tabel yang saling terhubung yang nantinya digunakan untuk mendapatkan keluaran sesuai dengan yang diinginkan, yang ditunjukan pada gambar 2 . 


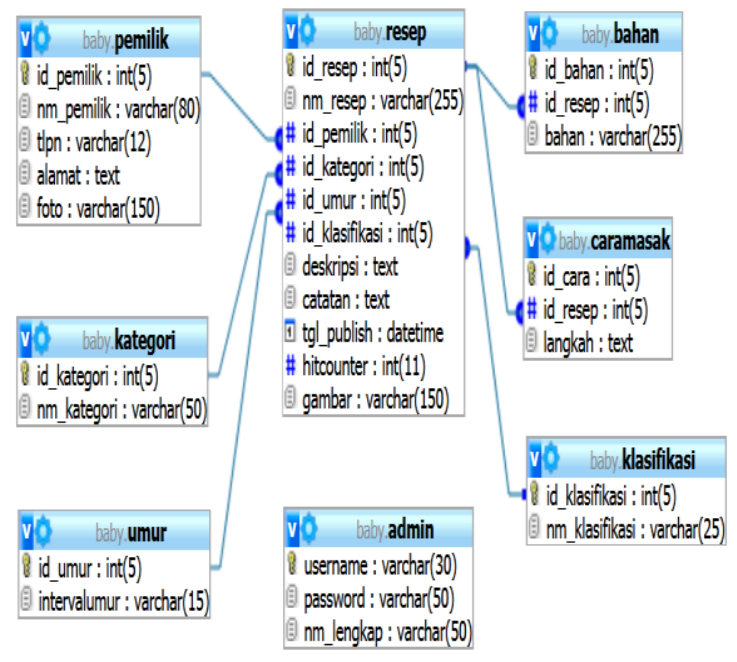

Gambar 2 Relasi Tabel

\section{Hasil dan Pembahasan}

Hasil implementasi penelitian berdasarkan analisis yang telah dilakukan yang mencakup implementasi sistem serta tahap-tahap pengujian dari sistem yang telah dibuat untuk mengetahui tingkat keberhasilan dari sistem tersebut

a. Hasil pengujian sistem

Pengujian yang dilakukan meliputi pengujian black box terhadap segala fitur dan fungsi dalam sistem yang ditunjukan dalam tabel 1.

Tabel 1 Hasil Pengujian

\begin{tabular}{|c|c|}
\hline Butir Uji & $\begin{array}{c}\text { Hasil } \\
\text { Pengujian }\end{array}$ \\
\hline Menampilkan dan filter umur & Berhasil \\
\hline $\begin{array}{l}\text { Menampilkan dan Membuat } \\
\text { Data Resep }\end{array}$ & Berhasil \\
\hline Menampilkan dan filter umur & Berhasil \\
\hline Mengolah data member & Berhasil \\
\hline $\begin{array}{l}\text { Menampilkan dan filter } \\
\text { Bahan }\end{array}$ & Berhasil \\
\hline $\begin{array}{l}\text { Pengkategorian resep } \\
\text { berdasarkan bahan }\end{array}$ & Berhasil \\
\hline $\begin{array}{l}\text { Pengkategorian resep } \\
\text { berdasarkan jenis }\end{array}$ & Berhasil \\
\hline Registrasi Member & Berhasil \\
\hline $\begin{array}{l}\text { Pengkategorian resep } \\
\text { berdasarkan Umur }\end{array}$ & Berhasil \\
\hline
\end{tabular}

\section{b. Tampilan Mobile Device}

Bagi para member yang ingin mengakses sistem ini melalui device mobile dalam hal ini seperti smartphone maka sistem repository mp-asi ini telah dimungkinkan. Hal ini disebabkan karena sistem dibangun menggunakan teknologi responsive. User yang ingin membaca resep, mengomentari atau ingin menjadi member agar memilih hak akses untuk mengupload resep sangat dimudahkan dengan teknologi responsive. Seperti ditunjukan pada gambar 3 .

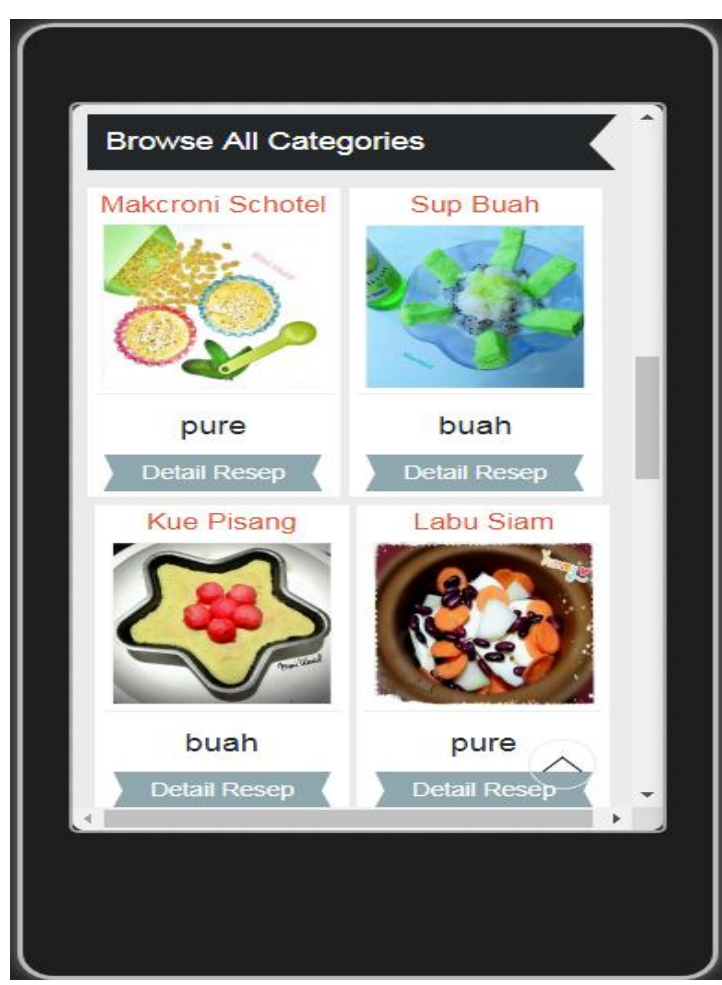

Gambar 3 Aplikasi MP-ASI Mobile

c. Tampilan web based

Tampilan desktop/web based untuk menampilkan informasi yang full layar. Sehingga user dengan bebas untuk mengakses setiap fitur dan menu yang tersedia dalam sistem. Gambar maupun detail produk telah disajikan dengan sangat sederhana sehingga diharapkan user/ member familier dalam menggunakannya. 


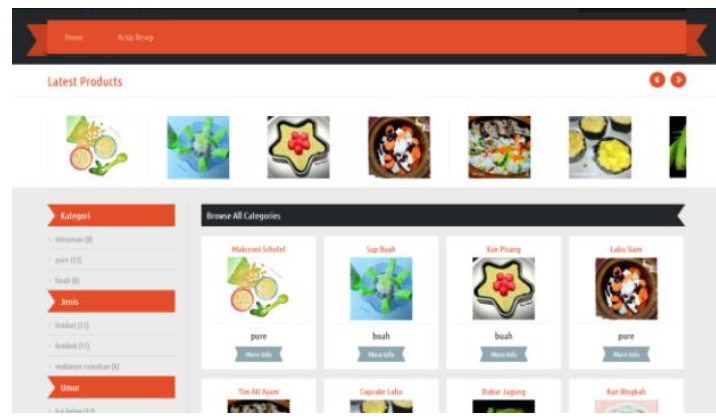

Gambar 4 Trend Plot Hasil Produksi

\section{d. Pengaturan Resep}

Pada halaman administrator, pengaturan fitur resep telah tersedia dengan tampilan seperti pada gambar 5 . Dalam informasi tersebut ditampilkan beberapa tombol untuk mengaturnya. Menu-menu tersebut berupa menu untuk melihat detail resep tersebut, mengubah atau bahkan untuk menghapus jika ada kesalahan informasi yang terjadikan dalam resep tersebut.

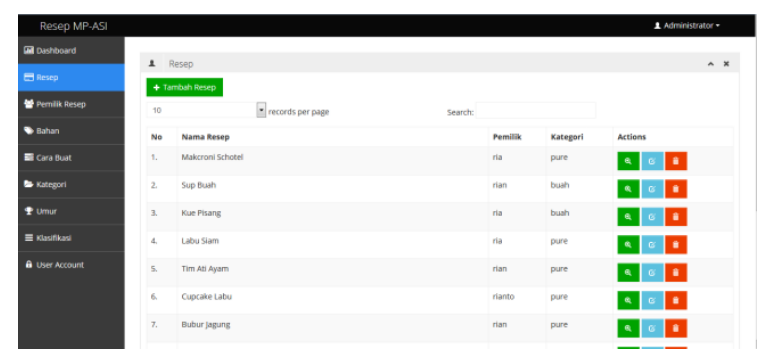

Gambar 5 Time Series

\section{e. Script pengaturan Resep}

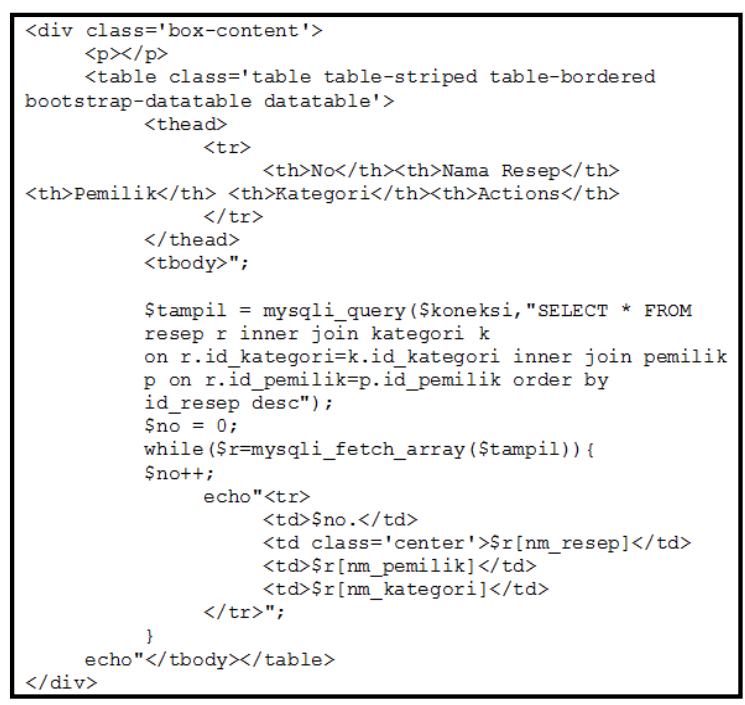

Gambar 6 Script Menu manajemen resep enjelasan : dalam listing coding ini diperintahkan untuk menampilkan data resep dalam bentuk tabel. Informasi yang tersaji dihasilkan dari proses query join tabel kategori, resep, pemilik. Sehingga informasi yang tersaji dapat diketahui pemilik/yang mengupload resep tersebut. Selain itu, juga telah ditampilkan informasi pengkategorian dari masingmasing resep tersebut. Berhubung skrip ini berada dihalaman admin, maka skrip ini juga telah disediakan link untuk melakukan penambahan, pengubahan dan penghapusan data resep.

\section{f. Script tampil resep bagi user}

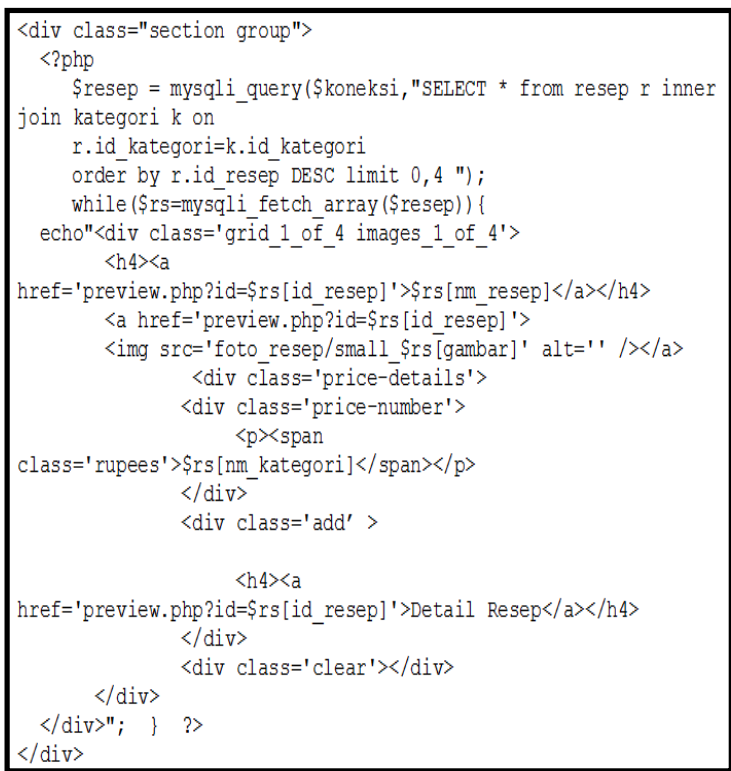

Gambar 7 Script Menu resep

\section{Penjelasan :}

Informasi untuk menampilkan detail dari resep yang akan ditunjukan pada halaman end user. Selain informasi berkaitan nama resep juga disediakan informasi berupa gambar-gambar dari resep-resep yang berhasil diupload oleh pada kreator kontentnya. Jika ada diantara resep yang ini dipreview telah tersedia menu yang telah dilinkan pada script preview. Dalam preview tersebut ditampilkan cara pembuatan, bahan-bahan yang digunakan dan informasi tentang pemilik resep. 


\section{Kesimpulan}

Berdasarkan penelitian yang telah dilakukan, dapat disimpulkan bahwa :

Sistem repository MP-ASI sangat membantu masyarakat dalam menambah wawasan dan pengetahuan cara penyajian MP-ASI yang mudah dan sederhana dengan bantuan resep-resep yang dipublish oleh para member dalam sistem ini.

\section{Daftar Pustaka}

[1] Suradi, R. B. (2010). Indonesia Menyusui. Jakarta: Badan Penerbit Ikatan Dokter Anak Indonesia.

[2] Departemen Kesehatan RI. (2006). Pedoman Umum Pemberian Makanan Pendamping Air Susu Ibu (MP-ASI) Lokal Tahun 2006. Jakarta: Depkes RI.

[3] Gumbira, E., \& Haritz, A. I. (2001). Manajemen Agribisnis. Jakarta: Ghalia Indonesia

[4] http://www.dewanpers.or.id/page/kebi jakan/pedoman/?id=494 